This article is (c) Emerald Group Publishing and permission has been granted for this version to appear here. Emerald does not grant permission for this article to be further copied/distributed or hosted elsewhere without the express permission from Emerald Group Publishing Limited. The article was published in Imdorf, Christian, Hegna, Kristinn and Reisel Liza (2015) Gender Segregation in Vocational Education, Comparative Social Research Vol 31, Bingley, UK: Emerald Insight. ISBN: 978-1-78560347-1 Final published version of the article is available here:

http://dx.doi.org/10.1108/S0195-631020150000031023

\title{
GENDER SEGREGATION IN VOCATIONAL EDUCATION: INTRODUCTION
}

\author{
Liza Reisel ${ }^{1}$, Kristinn Hegna ${ }^{2}$ and Christian Imdorf ${ }^{3}$
}

\begin{abstract}
This introductory chapter develops the overall research focus and the aim of the present special issue 'Gender segregation in vocational education'. Against the backdrop of strong horizontal gender segregation in vocational education and training (VET), we ask how institutional arrangements affect gendered (self-)selection into VET, and to what extent the patterns of the latter vary by context and over time. In order to expand our knowledge about the impact of educational offers and policies on gendered educational pathways and gender segregation in the labour market, we have gathered comparative quantitative studies that analyse the relationship between national variations in the organization of VET and cross-national differences in educational and occupational gender segregation from an institutional perspective. Following a review of the core literature within the field of gender segregation in VET, this introduction presents a discussion of education system classifications and institutional level mechanisms based on the contributions made in this volume. We then discuss gendered educational choices at the individual level, with particular emphasis on variation across the life course. Finally, we conclude our introductory chapter by commenting on the main contributions of the volume as a whole, as well as addressing suggestions for further research.
\end{abstract}

\footnotetext{
${ }^{1}$ Institute for Social Research, liza.reisel@socialresearch.no

${ }^{2}$ Department of Education, University of Oslo

${ }^{3}$ Institute of Sociology, University of Bern
} 
Educational institutions can be understood as "sorting machines" (Kerckhoff, 1995; Spring, 1976). Students from different backgrounds enter schools and colleges. With their acquired knowledge and credentials, they enter the labour market. We know that children coming from more privileged homes generally end up in more privileged positions in the labour market than children from lower educated and poorer families. Plenty of research has been done that describe and explain how privilege is reproduced through the education system, and how and when education can be used as a means of social mobility (Boudon, 1974; Bourdieu, 1986; Bourdieu \& Passeron, 1977; Bowles \& Gintis, 2002; Breen \& Jonsson, 2005; Brint \& Karabel, 1989; Chevalier, Denny, \& McMahon, 2004; Clark, 1960; Erikson \& Jonsson, 1996; Pfeffer, 2008; Reisel, 2011; van de Werfhorst, 2002). One of the mechanisms by which this happens is that educational institutions tend to steer students toward different educational and occupational destinations, based on qualities and characteristics that are highly correlated with their social background. Some of this sorting is self-sorting, when students (and/or their parents) choose different subjects or study programmes, and some of the sorting is institutional, when students are placed in different tracks, or at different proficiency levels, by teachers, advisors, school administrators or through organizational routines.

The "sorting machine" metaphor has most commonly been used in relation to socioeconomic background. But the education system also has a sorting function with regard to gender (Smyth \& Steinmetz, 2008, p. 261). How do women and men so often end up in different parts of the labour market? Part of the explanation, although there are many other mechanisms at play, is that boys and girls tend to choose different educational paths leading to different types of occupations (Trappe, 2006). Students may also be steered towards, or may be placed in, different tracks or proficiency levels by the educational institutions. Part of this selection is directly or indirectly influenced by gender. We expect that vocational education and training (VET) is particularly affected by these gendered processes of (self-)selection, given that the link between vocational education and occupational identities is clearer than in many general academic studies (Kupfer, 2014; Niemeyer \& Colley, 2015). However, little is known about how institutional arrangements affect gendered (self-)selection into VET, and to what extent the patterns vary by context and over time.

Most, if not all, theoretical models that aim to distinguish between different types of education systems and labour markets are developed in order to understand cross-national variation in inequalities that are associated with socioeconomic differences. Conversely, most models developed in order to understand gender segregation in the labour market fall short of linking labour market differences to specific characteristics of education systems. One notable exception is Margarita Estévez-Abe (2005; 2011) who analysed international variations in gender segregation in the labour market using the Varieties of Capitalism (VoC) framework (Hall \& Soskice, 2001). With this volume we hope to shed more light on 
the relationship between national variations in the organization of VET and cross-national differences in educational and occupational gender segregation.

\section{GENDER SEGREGATION IN VET AND SOCIAL INEQUALITY}

It is common to distinguish between two types of gender segregation in the labour market: vertical gender segregation and horizontal gender segregation. Vertical gender segregation refers to the differential position of men and women in the hierarchy of educational or occupational prestige and status. Vertical gender segregation is traditionally associated with male dominance, meaning that men tend to occupy the lion's share of the most prestigious and lucrative positions in society. Horizontal gender segregation refers to the differential distribution of men and women across educational programmes and occupations, industries and sectors in the labour market (Reisel \& Teigen, 2014a). Horizontal gender segregation in education means that male and female students are unequally distributed across subjects, courses, tracks, study programmes, types of schools and/or degree programmes.

It is useful to distinguish between the two types of segregation for analytical purposes. However, the two are interconnected in the sense that horizontal segregation tends to have consequences for vertical segregation. For example, it is commonly found that female typed occupations yield lower financial returns and fewer career opportunities compared to male typed occupations at the same level of education. This holds when comparing female- and male typed occupations that require vocational training certificates, such as nurses-aids and mechanics, and when comparing female- and male typed occupations that require Bachelor's degrees such as nurses and engineers.

There are several reasons why it is important to better understand the gender segregated patterns of educational choices, especially in VET. First, from the perspective of the individual, the extreme under-representation of one's own gender represents a barrier which may seem impossible to cross. This may prevent young men and women from choosing according to their preferences, and potentially makes it difficult for the few who do choose to be one of the few women in a male dominated education programme or the opposite (Lemarchant, 2007; Reisel \& Teigen, 2014b). Second, in countries where vocational education forms a significant part of the education system, male dominated vocational programmes tend to be associated with better labour market outcomes than female dominated vocational programmes, in terms of career prospects, salaries, work hours and status (Gundert \& Mayer, 2012). Furthermore, international research has established that occupational segregation is one of the major causes of the gender wage gap (Blau, Ferber, \& Winkler, 2006; Østbakken, Barth, \& Schøne 2014).

Third, from the perspective of society, it is inefficient that gender gets in the way of the match between interests, talent and abilities on the one hand and occupational destinations on the other. In several of the typical vocational professions, such as some of the health professions and technical crafts, 
there is a high demand for labour. If employers would be able to recruit more evenly among boys and girls (men and women) they would have a much larger pool of potential candidates. Finally, the strong patterns of gender segregation in vocational education challenge the common perception of VET as an integrative educational sector. Whereas, on the one hand, the early implementation of VET-programmes has the potential to integrate low school achievers into post-compulsory education (Buchholz, Imdorf, Hupka-Brunner, \& Blossfeld, 2012), providing them with skills and labour market qualifications, it simultaneously fosters gender segregation in education and - potentially - in the labour market. Hence, the aim of achieving more social equality regarding access to education and the labour market through expanding VET seems to be achieved at the cost of gender equality, as it contributes to the reproduction of educational gender segregation.

\section{About the volume}

The main motivation for assembling this volume was to gather international comparative research on patterns of gender segregation in vocational education and training around the world, and to increase our knowledge about this phenomenon in different national contexts. More specifically, we wanted to try to identify some of the institutional variation that seems to make a difference for the extent to which vocational education is gender segregated, and the ways in which the organization of VET affects occupational gender segregation. So far, comparative studies on gender segregation in VET hardly exist, and our knowledge about the impact of educational offers and policies on gendered educational pathways is therefore limited. In addition we wanted to include international contributions that focused on one or more individual level mechanisms in order to understand the phenomenon better.

The volume contains ten chapters. After the introductory chapter, the remaining chapters are divided into three parts. The first contains four chapters based on cross-country comparisons. The second contains within-country comparisons - one regional and one over time. The third includes three chapters that focus on theoretical contributions from a life course perspective, within single country settings.

In the following, we will present a review of the core literature within the field of gender segregation in vocational education and training. Following the literature review, we present a discussion of institutional level mechanisms based on the contributions made in this volume. We then discuss gendered educational choices at the individual level, with particular emphasis on variation across the life course. Finally, we conclude this introductory chapter by commenting on the main contributions of the volume as a whole, as well as addressing suggestions for further research. 


\section{WHAT DO WE KNOW ABOUT GENDER SEGREGATION IN VOCATIONAL EDUCATION?}

Although some research has been done on horizontal gender segregation in higher education, (e.g. Gerber $\&$ Cheung, 2008), the strong horizontal gender segregation in vocational education and training is not frequently addressed in quantitative studies. Still, research has been done on the topic in different European countries: United Kingdom (Fuller \& Unwin, 2013); Switzerland (Leemann \& Keck, 2005); Germany (Beicht \& Walden, 2012); France (Kergoat, 2014); Norway (Støren \& Arnesen, 2003); Sweden (Dryler, 1998). Moreover, three recent special issues on gender and education, two of which specifically address gender and vocational education, have brought together research on VET from a gender perspective (Kupfer, 2014; Lamamra, Fassa, \& Chaponnière, 2014; Niemeyer \& Colley, 2015). Yet, none of the special issues systematically interrogate cross-national variation from an institutional perspective, which is one of the main contributions of the current volume.

\section{Level and type of education}

Although various factors have been suggested to explain cross-national differences in occupational gender segregation, the interrelation between gender segregation in the labour market and gender segregation in education has often been neglected. Smyth (2005) has shown that there is a strong relationship between gender segregation in education and in the labour market in most European countries. However, since there are some countries where the association is weaker, institutional contexts might explain these differences. Based on a comparison across 17 European countries, Smyth and Steinmetz (2008) argue that horizontal gender segregation across different fields of study in higher education mediates part of, but far from all of, the association between gender and occupational segregation cross-nationally. They found that field of study within higher education was a stronger 'sorting mechanism' in some national systems than others.

One structural feature of the educational system that may make a difference is the size of the tertiary system and female tertiary participation, according to Charles and Bradley (2002). They find that both men and women are more likely to be found in female-typed jobs in countries with higher female labour market participation and a higher share of women in higher education. As will be elaborated later, the importance of the size of the vocational education system should also be studied in order to see how education may influence gender segregation in the labour market.

Another structural feature is the level of education. Previous research has studied the difference in segregation in secondary school compared to higher education (Imdorf \& Hupka-Brunner, 2015; Leemann \& Keck, 2005) and found evidence for a more pronounced horizontal segregation in upper secondary VET than at university level. In many European countries, the level of education would be 
highly correlated with the divide between vocational or applied education and general education - higher education studies being more often general in nature than secondary studies are.

\section{Comparative studies}

With regard to gender segregation in the labour market, a number of researchers have identified what they call a "welfare state paradox" (Birkelund \& Sandnes, 2003; Mandel \& Semyonov, 2006). This "paradox" refers to the counter-intuitive finding that more women friendly welfare states, like the Nordic countries, have more gender segregated labour markets than more conservative welfare states for instance in Southern Europe. Others argue that what seems like a paradox is not as paradoxical as one might think, and that the main reason why some countries seem to have less gender segregated labour markets is that a large share of the female typed (care) work is being carried out outside the labour market (Reisel \& Teigen, 2014c). In fact, several cross-national studies have found that high female labour market participation rates explain the comparatively high levels of gender segregation in otherwise more gender equal countries, like the Nordic countries (Barth, Hardoy, Schøne , \& Østbakken, 2014; Ellingsæter, 2013; Korpi, Ferrarini, \& Englund, 2013; Nermo, 2000).

In a study of inter-European differences in rates of female labour force participation and patterns of occupational sex segregation, Buchmann and Charles (1995, pp. 87-88) conclude that early tracking and a prominent reliance on vocational education may contribute to higher levels of sex segregation, and lower labour force commitment among women. They argue that early tracking is a challenge because adolescence is a period "when reluctance to transgress sex-role norms is great and when labour force experience is very limited". If the link between educational programmes and occupational destinations is strong, choices made at a young age will have consequences for labour market placement in the long run. A similar result was found in a study of cantonal differences in gender-typed school-to-work transitions in Switzerland, where the cantonal education systems with higher VET rates had a stronger allocation of men to male-typical occupational careers (Imdorf, Sacchi, Wohlgemuth, Cortesi, \& Schoch, 2014).

Comparing occupational sex typing in Switzerland and the United States, Charles, Buchmann, Halebsky, Powers, and Smith (2001, p. 387) have shown that women with a vocational degree are particularly likely to work in women-dominated occupations. They claim a mediating effect of educational system characteristics. They emphasize that early occupational decision making due to early tracking and tighter linkages of education and employment contribute to stronger and more persistent occupational sex typing in the case of Switzerland. This implies that the extent to which gender-specific human capital investment has consequences for labour market destinations, depends on the structure of education systems and their interconnections with the labour market. 


\section{Change over time}

Over the course of the second half of the $20^{\text {th }}$ century, education systems all across the Western world experienced a high degree of expansion. During this period, women went from being underrepresented to being overrepresented in higher education. Today it is commonplace that women are more likely than men to achieve Bachelor's and Master's degrees, and prestigious professions such as medicine and law have gone from being male dominated to being gender balanced or even female dominated. At the same time, many countries still have vocational education and training programmes that provide students with occupational specific skills without higher education qualifications. In contrast to a global trend toward declining gender segregation of majors in higher education (Gerber \& Cheung, 2008), vocational programmes have been remarkably stable over time in their gender profile, where women rarely choose educational programmes in crafts and technical subjects and men rarely choose educational programmes in health and welfare related subjects. In their research paper about apprenticeships and gender segregation in the UK, Fuller and Unwin (2013) find only a small recent reduction in the size of the gender imbalance in several of the service sectors. Little progress has been made in changing gender stereotypical participation in apprenticeships in sectors such as construction, childcare, engineering and plumbing. Despite some reduction in the size of the gender imbalance in the service sectors due to a small but slowly growing proportion of male participation in female-typed service sectors (e.g. in childcare apprenticeships), a similar expansion in female participation in service sectors traditionally dominated by males has not been matched.

\section{INSTITUTIONAL LEVEL MECHANISMS}

\section{Classifications of educational systems}

There have been a number of attempts to classify countries according to similarities and differences in institutional contexts. Gøsta Esping-Andersen's Three worlds of welfare capitalism (Esping Andersen, 1990 ) is a well-known example. The Varieties of Capitalism framework mentioned above (Hall \& Soskice, 2001), is another. Yet, although public policy and labour market structures are intertwined with education systems (Maurice, Sellier, \& Silvestre, 1986), they do not neatly align in the sense that they form a coherent pattern of institutional clusters. Still, insofar as such comparative approaches refer to educational structures, they may be useful for understanding gender relations in education as well.

Different types of education systems have been classified for example according to their levels of stratification, diversification, standardization and expansion (Arum, Gamoran, \& Shavit, 2007; Jonsson \& Erikson, 2007; Shavit \& Blossfeld, 1993). Éric Verdier has proposed a typology of five education policy regimes that are present to larger or smaller extent in specific country contexts (Verdier 2013). He argues that there has been a recent historical shift toward life-long learning (LLL) in the European context, 
which brings about an increasing hybridization of vocational education and training systems. $\mathrm{He}$ distinguishes between education systems that build on a corporatist, academic, universal, pure market or organized market models. He labels the three former "decommodified" LLL regimes, and the two latter LLL market regimes.

Another very similar typology focuses more specifically on different vocational education systems (Greinert, 2004; Nyen \& Tønder, 2014). Based on six core factors, different vocational education models can be distinguished. The six factors are defined as 1) who controls content and structure, 2) if and how this is regulated, 3) what kind of skills and competencies are developed (general or specific), 4) where the training is carried out, 5) how the training is financed, and 6) what type of identity the participants develop. Some of these factors tend to occur together, such that more state controlled systems tend to focus on more general skills, with training in schools rather than in firms. Likewise, more market controlled systems tend to focus more on firm specific skills with firm specific training. A third type is corporatist, meaning that the social partners are central in controlling the content and structure vocational training programmes, and the focus is more on industry specific skills with standardized occupational training through apprenticeships. These three types (state controlled, market controlled and vocation based) are closely related to the labour market structure and general social structure, such as labour relations, company management, basic and higher education and the labour market (cf. Verdier, 2013, p. 70). One of the consequences of this structural embeddedness is that there has been very little "policy learning" across countries in this field (Nyen \& Tønder, 2014). In contrast to for instance the harmonization of higher education within Europe according to the Bologna accords ${ }^{4}$, the institutional make-up of VET remains relatively distinct across countries.

None of these typologies have so far been investigated with regard to variation in gender segregation in vocational education. As mentioned above, the notable exception is Margarita Estevéz-Abe (Estevez-Abe, 2005; Estévez-Abe, 2011) who uses the Varieties of Capitalism (VoC) framework to explain the link between skill formation "regimes" and international variations in gender segregation in the labour market (cf. McCall \& Orloff, 2005). The VoC framework distinguishes between two main types of labour markets - coordinated labour markets and liberal labour markets. One of the elements of this distinction is the characteristics of the main patterns of skill formation across countries. In the coordinated labour markets the tendency is to have some kind of apprenticeship system and to develop firm specific or industry specific skills. In the liberal labour markets, by contrast, more general skills are developed in school and college settings, and the firm or industry specific vocational education is marginal. Estévez-Abe has applied this theory to the question of gender segregation and argues that firm specific, and to some extent industry specific skills are biased against women because of women's

\footnotetext{
${ }^{4}$ http://www.ehea.info/
} 
expectations of labour market interruptions and discrimination. The result is that these kinds of vocational education systems concentrate men in male jobs, more so than other education systems (Estévez-Abe, 2011).

However, the empirical evidence for the link between skill type, women's expectations and labour market segregation is scarce. The analysis has been criticized for ascribing cross-national difference to spurious institutional variation, arguing instead that a country's level of post-industrial economic development is a more powerful predictor of occupational segregation by gender (Charles, 2005). Even though there is a correlation between skill development "regime" and gender segregation at the macro level, the mechanisms explaining women's and men's gendered educational choices are not very well understood.

In this volume, we are among other things interested in whether or not clusters of education systems vary with regard to gender segregation in vocational education and training. Several of the comparative contributions investigate whether specific organizational features of vocational education systems have consequences for the level of gender segregation in occupational expectations, gendered educational choices and labour market destinations. The four dimensions that are directly or indirectly tested are vocational orientation, tracking, vocational specificity and occupational domains. Vocational orientation or enrolment refers to the size of the vocational offer, that is, the proportion of students enrolled in vocational education and training versus general or academic programmes. This measure captures the relative importance of vocational education in the overall educational system in a country. In existing research, tracking has been investigated along several dimensions (Buchmann \& Charles, 1995; Charles, et al., 2001; Hadjar \& Berger, 2011). It can refer to the timing of tracking, that is, the age at which students have to choose or are placed in a study track. It can also refer to the extent to which students are tracked. For example how many tracks there are or for how long students are tracked. Finally, it can refer to the flexibility of the tracks, for example how difficult it is to change tracks after enrolment. Tracking has been seen as important, linking it to gender identity development in adolescence and the question of whether early decisions have long-term consequences. The degree of vocational specificity is a feature that directly links back to Estevez-Abe's theory about the type of skills learned and the nature of the link to the labour market (Estévez-Abe, 2005). Vocational specificity thus refers to the extent to which available vocational programmes are closely linked to occupational requirements. The more general the skills taught, the easier they are translated to a variety of occupations. The last dimension is occupational domain, which refers to the breadth or range of occupations included in the vocational education and training part of the education system. In some countries the types of occupations you can qualify for through vocational education is limited within a few industries, while in other countries qualifications for a wide variety of occupations are available through the vocational education system. In Verdier's 
typology (Verdier, 2013) the vocational principle would be closely associated with institutional arrangements with strong vocational orientation, wide occupational domains and high vocational specificity. In educational systems that are influenced by the universalistic principle, tracking would be minimal and flexible. The academic principle would be associated with low vocational specificity and weak vocational orientation.

\section{NEW INSIGHTS ON INSTITUTIONAL LEVEL MECHANISMS}

Until now these institutional features have mostly been studied systematically as mechanisms contributing to social class differences in educational attainment (see e.g. Bol \& Van de Werfhorst, 2013), except for the vocational skill specificity question, about which the literature is inconclusive. Four of the chapters in this book however, investigate whether organizational aspects of different vocational education systems are related to the gender segregation of occupational expectations, educational choice and occupations respectively ${ }^{5}$.

The first of these is the vocational orientation of a system; Steffen Hillmert shows that in countries with a high proportion of students in upper secondary VET, the occupational expectations of 15 year old male students show a higher degree of gender-typicality, while the opposite is true for female students. In their regional analysis of gender differences in the Bulgarian education system, IlievaTrichkova, Stoilova and Boyadjieva find higher shares of women in initial vocational education and training (IVET) in regions with a higher offer of vocational education. Moreover, and in line with Hillmert's findings, the authors point to higher shares of women in engineering courses in Bulgarian districts where not only the offer of vocational education but also the share of the industrial sector is higher. Further, Imdorf, Hegna, Eberhard and Doray show in their comparison of Germany, Norway and Canada that gender segregation in education increases with an increasing amount of vocational programmes on offer, with men being particularly likely to be concentrated in male dominated fields. Also, as Smyth and Steinmetz show in their analyses of variations across Europe, among men the chances of being in a male-typed job are greater in systems with a higher proportion enrolled in vocational courses, but this is not associated with the gendering of jobs for women. This tendency among men is even more pronounced for those with VET qualifications, according to the authors. Thus, based on these chapters, it seems reasonable to conclude that a high degree of vocational orientation of an upper secondary school system contributes to the gendering of education and occupational trajectories for men, but less so for women.

\footnotetext{
${ }^{5}$ The organizational dimensions of VET underlining these attempts has been operationalized in different ways, and

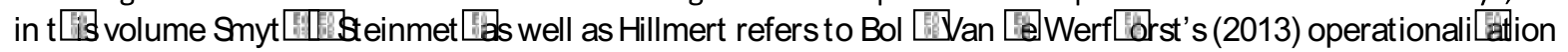
of tracking, enrollment and specificity.
} 
The second is regarding aspects of tracking where the contributions in this book show mixed results. Imdorf et al. find that late tracking is associated with less gender typical educational choices, but Smyth and Steinmetz find that tracking is also associated with less gender typical occupational destinations, particularly among men. At the individual level, Hillmert shows that tracking decreases the gender-typing of expectations among men, but increases the gender-typing of expectations for women. On the other hand, Hillmert finds no association between the tracking of an educational system and the gendering of occupational expectations or occupations in the labour market at the country level. One must bear in mind however, that the tracking indices used by Hillmert and Smyth \& Steinmetz combine the level and timing of tracking in one index. Imdorf et al. who include the specific age of tracking when comparing Germany and Norway find that the older male respondents are when they start their educational programme, the less likely it is that they enrol in gender-typed programmes, all else being equal. A similar age effect for women can be found in Germany, whereas the opposite can be observed for women in Norway: the older the female students are, the more often they enrol in female-typed programmes, everything else being equal. The authors speculate that the latter finding could be explained by the high number of women obtaining higher education qualifications for female-typed occupations in the large Norwegian public welfare sector.

Third, in the contributions of this volume vocational specificity does not seem to make much difference for the gender segregation of occupational expectations or occupational destinations. However, Smyth and Steinmetz find that in systems with a higher degree of VET specificity, male graduates have a higher risk of non-employment if they do not graduate with vocational qualifications. Men are also somewhat more likely to enter typically male jobs in these systems but this tendency does not vary by whether the qualification is vocational. Hillmert shows that vocational specificity has no overall effect on occupational expectations, but when mid-level occupations (those between managerial/ professional occupations and unskilled occupations) are compared to other occupations, the former is associated with higher gender segregation in expectations. Ilieva-Trichkova et al. conclude from their Bulgarian study that the specificity of the local economy, measured by the regional share of the industrial sector, can play a role in determining the chances of young women to choose vocational education, if the specificity of the field of study (engineering in their case) is taken into account.

Looking at the effects of occupational domains - the breadth of occupations in VET - it is likely that it generally overlaps with the vocational orientation of the VET system - i.e. the size of the VET sector. According to the analyses that specifically test this dimension, in the chapter by Smyth and Steinmetz, it does not seem to have much additional explanatory power regarding the gender segregation of occupations. 
Institutional differences also have consequences for the gender wage gap, presumably through gender segregation across occupations. In the first chapter of this volume, Triventi and colleagues present findings on gender inequalities at labour market entry, based on a large international comparative project. When comparing analyses across 13 countries they conclude that among labour market entrants with vocational qualification, gender wage inequalities seem to be noticeable in countries where educational systems display a strong reliance on vocational education and training (e.g. Hungary, Switzerland, Germany). Conversely, they found that in a number of countries where the educational system provides more general knowledge and is less vocationally specific, women face the highest wage penalty among the lowest- (Italy) or highest-educated (Estonia, Russia, Italy). 


\section{INDIVIDUAL LEVEL MECHANISMS FROM A LIFE COURSE PERSPECTIVE}

Although systematic comparative differences at the institutional level can tell us something about which institutional factors may have an impact on the extent to which vocational education and/or the labour market is gender segregated, they do not in themselves explain the mechanisms through which gender segregation is maintained or potentially may change.

Theoretically, women and men are assumed to have differential affinities and values, women for human interaction (contact with or helping other people) and men for technical specialization, income, promotion, or recognition (Busch-Heizmann, 2015). It is possible that there are biological reasons for these average differences in preferences, although there are large variations among men and among women in this respect. It is also possible that the ways in which boys and girls are raised allow them to develop these skills to varying extents. Given that there are these average gender differences in preferences and skills, it is argued that women will have comparative advantages over men in occupations in which human interaction and communication are significant components, and men will have comparative advantages over women in occupations where technical abilities are a significant component. Yet, the question remains what actually makes a difference for gendered educational choices, since there seems to be significant variation both within gender and across contexts.

First, VET is argued to be more segregated by gender than education that offers general skill acquisition, because employment opportunities for women who pursue industry specific skills differ in terms of certainty and risk (Estévez-Abe, 2011). Women who do engage with VET are understood to pursue gendered pathways; for example, they tend to seek school based rather than apprenticeship, onthe-job, and employer mediated training in order to avoid the possibility for employer based gender discrimination, and aim to acquire portable skills with low "atrophy rates". In this volume, Pullman and Andres analyse data from Canada and find relatively high degrees of mobility between the two types of studies, with applied, more labour market oriented courses generally being taken by both men and women at a later stage in the educational career. The authors therefore conclude that women do not necessarily choose the most general skill pathways.

Second, gendered socialization is routinely referred to as an important explanation for gendered educational and occupational choices. The basic premise for gendered socialization is that boys and girls are treated differently and are met with divergent expectations from very early on, with consequences for the types of preferences, skills and expectations they develop. In her contribution to this volume, Sikora specifically investigate occupational expectations, science self-concept, as well as parental employment in science, as predictors for women's and men's probability of enrolling in science related VETprogrammes. She finds strong links between occupational expectations related to the sciences among 15 year olds and later enrolment in sciences. She concludes that self-segregation of youth through career 
plans and subject specialisation lays the foundation for later divides in post-secondary education in Australia.

Finally, identity theory is frequently referred to in the literature on gender segregation. One widely cited argument is that when educational track choices are made in secondary school, the choices are made when gender identity is at its height of negotiation. This is part of the explanation for why so many young students still make gendered educational choices. Moreover, gender incongruent behaviour is more heavily sanctioned among boys than among girls, which may be one of the reasons why we see more gender atypical educational choices among women than among men (England, 2010). Along the same lines Gottfredson (1981) claims that two dimensions - sex-type and prestige level - are the central categories adolescents use in order to classify different occupations long before they actively start to think about which professional activities could match their interests. These two dimensions effectively narrow down the range of educational programmes students even consider. This theoretical perspective implies that older students would be less sensitive to how their educational choices are viewed by others. However, Eberhard et al. in this volume find that it is educational level, not age that accounts for the association between gender congruent choices and perceived social approval. In their German sample, women with Abitur (highest level upper-secondary diploma) do not expect as negative a reaction to the choice of a typically male-dominated occupation as women with Hauptschulabschluss (lowest level secondary school diploma), all else being equal.

These individual level mechanisms are useful for explaining why there is relatively little change over time in gendered educational choices. They also to some extent explain why women are more likely to make non-traditional choices than men. The particular alignment between girls' higher academic achievement and the attractiveness of (previously) male dominated occupations requiring higher education, further help explain why so few girls enrol in male dominated VET programmes. In their chapter on the feminization of skilled crafts training occupations in Germany, Haverkamp and Runst document a modest trend towards desegregation, primarily due to substantial increase in the proportion of women found in the group of integrated occupations. At the same time, they also show that there are a few VET apprenticeship categories that have experienced a shift from male dominated towards gender mixed in Germany during the years 2005-2013. However, their analysis shows that the change over time is driven by the withdrawal of men, not the influx of larger numbers of young women choosing to enter a male dominated field.

The findings in this volume suggest that some individual theories may be more valid than others at different institutional transition points. For example, it is in discussions of the effects of tracking that identity theory is made most relevant. Imdorf et al. argue that identity theory might be more powerful to explain horizontal gender segregation in upper-secondary VET, whereas rational choice arguments might 
be better suited to explain gender-typed educational choices at the post-secondary level, or in less rigorously tracked systems. This may be taken as an argument for combining individual and institutional level explanations for gender segregation. It is when institutional conditions intersect with individual choices that patterns of gender segregation is produced and reproduced.

\section{CONCLUDING REMARKS}

Together, the contributions to this volume advance our understanding of gender segregation in VET from a comparative perspective. On the one hand, the various chapters test a number of hypotheses regarding the effect of different types of VET-systems on gender segregation in educational expectations, in the education system and in the labour market. Specifically, Imdorf et al. apply the academic, vocational, and universal policy principles in order to select and compare three countries (Germany, Norway, Canada) characterized by a different mix of these principles. Their chapter addresses how each principle impacts differently on horizontal gender segregation in education. They find stronger gender segregation in upper secondary VET than in higher education in Germany and Norway, as well as for vocational (compared to academic) post-secondary programmes in Canada. However, because the share of vocational programmes in Canada is relatively small, the overall gender segregation in education is lower in Canada than in Germany, where the vocational principle historically has been particularly strong. The Norwegian education system is built on a hybrid between the vocational principle and the universalistic principle, where the vocational principle is much stronger for the male-typed educational programmes than for the female-typed programmes. The universalistic principle results in vertical permeability in the educational system and allows a considerable number of male VET graduates to proceed to higher education where they more frequently enrol in gender-mixed study programmes than in upper secondary VET.

On the other hand, some of the contributions also challenge common assumptions about education that tend to underlie research on educational inequalities and their consequences for labour market outcomes. Pullman and Andres, for example, look at women's and men's involvement with applied and general fields of study in higher education, and find considerable movement between general and applied/vocational fields over the life course in Canada. Their findings highlight that educational choices are not necessarily made at one point in a person's life, but that they instead evolve over time in a way that is consistent with Verdier's (2013) thesis on lifelong learning. Again, individual movement relies on the premise that the institutional organization of the educational system allows this kind of flexibility. Another example is Sikora's chapter that compares science related post-secondary VET with science related degree programmes at university. Research on male dominated VET tends to focus on the manual labour aspect of the occupations, rather than the science related aspects. Through focusing on science, Sikora finds clear similarities in gender segregation between VET and university studies, where men dominate in the physics, engineering and technology, regardless of the type of qualification. 
According to Sikora, the main reason why science appears less gender segregated at university level, is simply that physics, engineering and technology do not dominate the sciences as much at university level as they do in post-secondary VET, due to the inclusion of the more gender balanced life sciences at the university level.

Finally, an important finding that reoccurs through many of the contributions is that men and their educational choices are central to the dynamics of gender segregation in VET. Haverkamp and Runst show that in the few instances that feminization of male dominated apprenticeship programmes occur in Germany the development is driven primarily by a decrease in male applicants. Sikora finds that men consistently dominate physics, engineering and technology programmes, regardless of whether they are vocationally oriented or university studies. Imdorf et al. find that men are particularly likely to be concentrated in gender-typical VET or applied programmes, in all three countries they compare (Germany, Canada and Norway), and Smyth and Steinmetz find that men have a greater chance of being in a male-typed job in systems with a higher proportion enrolled in vocational courses. They conclude that VET system characteristics make relatively little difference to occupational outcomes among women. At the other end of the spectrum, Pullman and Andres show that in Canada both men and women are likely to transition to studies in health fields and education after having had a relatively long engagement through higher education. Among the students who have these long educational trajectories, men are more likely than women to earn Master's degrees and professional degrees.

For further research, we suggest to follow up on three central themes that we have identified in this volume. First, the contributions have addressed some institutional mechanisms, but their findings are far from conclusive. Vocational orientation seems to make a difference for educational and occupational gender segregation, but vocational specificity and occupational domain do not. The results for the effects of tracking are mixed and need further investigation. In addition, system characteristics seem to have different consequences for different types of students, which implies that the intersection of gender, class and age should be taken into account. Second, we have identified a need for further research on dynamics across the life course with regard to gender segregation in VET and related educational and occupational choices. Finally, we encourage a more explicit focus on men and their educational choices. In what contexts are men more or less likely to choose female dominated or gender balanced VET programmes, and what labour market consequences do these choices have? The present volume contains important empirical research that hopefully will inspire further research on the topic of gender segregation in VET, as well as the conditions under which the current patterns of inequality are likely to change. 


\section{ACKNOWLEDGEMENTS}

The editors would like to thank the Norwegian Research Council for financial support through the FINNUT program, project no. 234053 Comparative Study of Gender Segregation in VET - institutional and individual perspectives, and the VAM program, project no. 236770 Gender Segregation in the Labor Market: Comparative Perspectives and Welfare State Challenges.

\section{REFERENCES}

Arum, R., Gamoran, A., \& Shavit, Y. (2007). More Inclusion Than Diversion: Expansion, Differentiation and Market Structure in Higher Education. In Y. Shavit, R. Arum \& A. Gamoran (Eds.), Stratification in Higher Education: A Comparative Study. Stanford, CA: Stanford University Press.

Barth, E., Hardoy, I., Schøne , P., \& Østbakken, K. M. (2014). Hva betyr høy yrkesdeltakelse for kjønnssegregering. In L. Reisel \& M. Teigen (Eds.), Køønnsdeling og etniske skiller på arbeidsmarkedet (pp. 108-118). Oslo: Gyldendal Akademisk.

Beicht, U., \& Walden, G. (2012). Berufswahl und geschlechtsspezifische Unterschiede beim Zugang zu betrieblicher Berufsausbildung. Zeitschrift für Berufs-und Wirtschaftspädagogik, 108(4), 491510.

Birkelund, G. E., \& Sandnes, T. (2003). Paradoxes of Welfare States and Equal Opportunities: Gender and Managerial Power in Norway and the USA. Comparative Social Research, 21, 201-241.

Blau, F. D., Ferber, M. A., \& Winkler, A. E. (2006). The Economics of Women, Men, and Work, 5th Edition. Upper Saddle River, NJ: Prentice Hall.

Bol, T., \& Van de Werfhorst, H. G. (2013). Educational systems and the trade-off between labor market allocation and equality of educational opportunity. Comparative Education Review, 57(2), 285308.

Boudon, R. (1974). Education, Opportunity, and Social Inequality. New York, NY: John Wiley \& Sons, Inc.

Bourdieu, P. (1986). The Forms of Capital. In J. G. Richardson (Ed.), Handbook of Theory and Research for the Sociology of Education (pp. 241- 258). New York: Greenwood Press.

Bourdieu, P., \& Passeron, J. C. (1977). Reproduction in Education, Society and Oulture. London and Beverly Hills: Sage.

Bowles, S., \& Gintis, H. (2002). The Inheritance of Inequality. The Journal of Economic Perspectives, 16(3), 3-30. doi: 10.2307/3216947

Breen, R., \& Jonsson, J. O. (2005). Inequality of Opportunity in Comparative Perspective: Recent Research on Educational Attainment and Social Mobility. Annual Review of Sociology, 31, 223243.

Brint, S., \& Karabel, J. (1989). The Diverted Dream: Community Colleges and the Promise of Educational Opportunity in America, 1900-1985. New York: Oxford University Press inc.

Buchholz, S., Imdorf, C., Hupka-Brunner, S., \& Blossfeld, H.-P. (2012). Sind leistungsschwache Jugendliche tatsächlich nicht ausbildungsfähig? KZTSS Kölner Zeitschrift für Soziologie und Sozialpsychologie, 64(4), 701-727.

Buchmann, M., \& Charles, M. (1995). Organizational and institutional factors in the process of gender stratification: Comparing social arrangements in six European countries. International Journal of Sociology, 66-95.

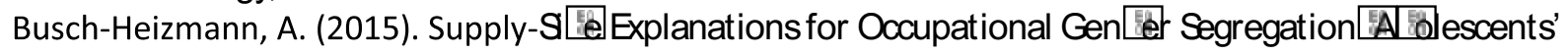
Work Values and Gender-(A) Typical Occupational Aspirations. European Sociological Review, 31(1), 48-64. 
Charles, M. (2005). National skill regimes, postindustrialism, and sex segregation. Social Politics, 12(2), 289-316. doi: 10.1093/sp/jxi015

Charles, M., \& Bradley, K. (2002). Equal but separate? A cross-national study of sex segregation in higher education. American Sociological Review, 67(4), 573-599.

Charles, M., Buchmann, M., Halebsky, S., Powers, J. M., \& Smith, M. M. (2001). The Context of Women's Market Careers: A Cross-National Study. Work and Occupations, 28(3), 371-396. doi: $10.1177 / 0730888401028003006$

Chevalier, A., Denny, K., \& McMahon, D. (2004). A multi-country study of inter-generational educational mobility. http://www.hks.harvard.edu/inequality/Summer/Summer04/papers/Denny2004.pdf Retrieved March 7th 2010.

Clark, B. R. (1960). The Cooling-Out Function in Higher Education. American Jurnal of Sociology, 65(6), 569-576.

Dryler, H. (1998). Parental Role Models, Gender and Educational Choice. The British burnal of Sociology, 49(3), 375-398. doi: 10.2307/591389

Ellingsæter, A. L. (2013). Scandinavian welfare states and gender (de) segregation: Recent trends and processes. Economic and Industrial Democracy, 34(3), 501-518. doi: $10.1177 / 0143831 \times 13491616$

England, P. (2010). The gender revolution: Uneven and Stalled. Gender and Society, 24(2), 149-166. doi: $10.2307 / 27809263$

Erikson, R., \& Jonsson, J. O. (1996). Can Education be Equalized? The Swedish Case in Comparative Perspective. Boulder, Colorado: Westview Press.

Esping Andersen, G. (1990). The Three Worlds of Welfare Capitalism. Cambridge: Polity Press.

Estevez-Abe, M. (2005). Gender bias in skills and social policies: the varieties of capitalism perspective on sex segregation. Social Politics: International Studies in Gender, State \& Society, 12(2), 180215.

Estévez-Abe, M. (2005). Gender Bias in Skills and Social Policies: the varieties of capitalism perspective on sex segregation. International Studies in Gender, State \& Society, 12(2), 180-215.

Estévez-Abe, M. (2011). Gender Bias of Education Systems. Femina Politica(2), 33-45.

Fuller, A., \& Unwin, L. (2013). Gender segregation, apprenticeship and the raising of the participation age in England: are young women at a disadvantage? : London: Centre for Learning and Life Chances in Knowledge Economies and Societies http://www.llakes.org/wpcontent/uploads/2013/12/44.-Fuller-and-Unwin.pdf.

Gerber, T. P., \& Cheung, S. Y. (2008). Horizontal stratification in postsecondary education: Forms, explanations, and implications. [Review]. Annual Review of Sociology, 34, 299-318. doi: 10.1146/annurev.soc.34.040507.134604

Gottfredson, L. S. (1981). Circumscription and compromise: A developmental theory of occupational aspirations. Journal of Counseling psychology, 28(6), 545.

Greinert, W.-D. (2004). European vocational training systems: the theoretical context of historical development.

Gundert, S., \& Mayer, K. U. (2012). Gender segregation in training and social mobility of women in West Germany. European Sociological Review, 28(1), 59-81.

Hadjar, A., \& Berger, J. (2011). Geschlechtsspezifische Bildungsungleichheiten in Europa: Die Bedeutung des Bildungs-und Wohlfahrtsstaatssystems Geschlechtsspezifische Bildungsungleichheiten (pp. 23-54): Springer.

Hall, P. A., \& Soskice, D. (Eds.). (2001). Varieties of capitalism: the institutional foundations of comparative advantage. New York: Oxford University Press.

Imdorf, C., \& Hupka-Brunner, S. (2015). Gender differences at labor market entry in Switzerland. In H.-P. Blossfeld, J. Skopek, M. Triventi \& S. Buchholz (Eds.), Gender, Education and Employment: An 
International Comparison of School-to-Work Transitions (pp. 260-279). Cheltenham, UK and Northampton, MA, USA: Edward Elgar.

Imdorf, C., Sacchi, S., Wohlgemuth, K., Cortesi, S., \& Schoch, A. (2014). How cantonal education systems in Switzerland promote gender-typical school-to-work transitions. Swiss Jurnal of Sociology, 40(2), 175-196.

Jonsson, J. O., \& Erikson, R. (2007). Sweden. Why Educational Expansion Is Not Such a Great Strategy for Equality: Theory and Evidence. In Y. Shavit, R. Arum \& A. Gamoran (Eds.), Stratification in Higher Education: A Comparative Study (pp. 113-139). Stanford, California: Stanford University Press.

Kerckhoff, A. C. (1995). Institutional Arrangements and Stratification Processes in Industrial Societies. Annual Review of Sociology, 21, 323-347. doi: 10.2307/2083414

Kergoat, P. (2014). Le travail, l'école et la production des normes de genre. Filles et garçons en apprentissage (en France). Nouvelles Questions Féministes, 33(1), 16-34.

Korpi, W., Ferrarini, T., \& Englund, S. (2013). Women's Opportunities under Different Constellations of Family Policies in Western Countries: Gender, Class and Inequality Tradeoffs Re-examined. Social Politics, 20(1), 1-40.

Kupfer, A. (2014). The interrelation of twenty-first-century education and work from a gender perspective. International Studies in Sociology of Education, 24(1), 113-125. doi: 10.1080/09620214.2014.895142

Lamamra, N., Fassa, F., \& Chaponnière, M. (2014). Formation professionnelle: I'apprentissage des normes de genre. Nouvelles Questions Féministes, 33(1), 8-14.

Leemann, R. J., \& Keck, A. (2005). Der Übergang von der Ausbildung in den Beruf. Neuchątel: Bundesamt für Statistik.

Lemarchant, C. (2007). La mixité inachevée. Garçons et filles minoritaires dans les filières techniques. Travail, genre et sociétés, 18, 47-64.

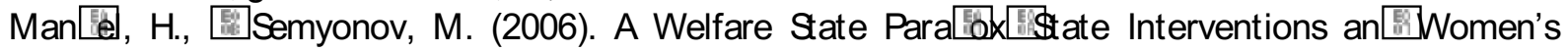
Employment Opportunities in 22 Countries. American Jurnal of Sociology, 111(6), 1910-1949. doi: 10.1086/499912

Maurice, M., Sellier, F., \& Silvestre, J.-J. (1986). The social foundations of industrial power: a comparison of France and Germany. Cambridge, MA: MIT Press.

McCall, L., \& Orloff, A. S. (2005). Introduction to Special Issue of Social Politics:" Gender, Class, and Capitalism". Social Politics: International Studies in Gender, State and Society, 12(2), 159-169.

Nermo, M. (2000). Models of Cross-National Variation in Occupational Sex Segregation. European Societies, 2(3), 295-333. doi: 10.1080/146166900750036295

Niemeyer, B., \& Colley, H. (2015). Why do we need (another) special issue on gender and VET? Jurnal of Vocational Education \& Training, 67(1), 1-10. doi: 10.1080/13636820.2014.971498

Nyen, T., \& Tønder, A. H. (2014). Yrkesfagene under press. Oslo: Universitetsforlaget.

Pfeffer, F. T. (2008). Persistent Inequality in Educational Attainment and its Institutional Context. European Sociological Review, 24(5), 543-565. doi: 10.1093/esr/jcn026

Reisel, L. (2011). Two Paths to Inequality in Educational Outcomes: Family Background and Educational Selection in the United States and Norway. Sociology of Education, 84(4), 261-280.

Reisel, L., \& Teigen, M. (Eds.). (2014a). Køønsdeling og etniske skiller på arbeidsmarkedet. Oslo: Gyldendal Akademisk.

Reisel, L., \& Teigen, M. (2014b). Det kjønnsdelte arbeidsmarkedet. In L. Reisel \& M. Teigen (Eds.), Køønnsdeling og etniske skiller på arbeidsmarkedet (pp. 11-28). Oslo: Gyldendal Akademisk.

Reisel, L., \& Teigen, M. (2014c). Vaner og vendepunkter. In L. Reisel \& M. Teigen (Eds.), Kønnsdeling og etniske skiller på arbeidsmarkedet (pp. 221-232). Oslo: Gyldendal Akademisk.

Shavit, Y., \& Blossfeld, H.-P. (Eds.). (1993). Persistent Inequalities: a Comparative Study of Educational Attainment in Thirteen Countries. Boulder, Colorado: Westview Press. 
Smyth, E. (2005). Gender differentiation and early labour market integration across Europe. European Societies, 7(3), 451-479. doi: 10.1080/14616690500194084

Smyth, E., \& Steinmetz, S. (2008). Field of Study and Gender Segregation in European Labour Markets. International Journal of Comparative Sociology, 49(4-5), 257-281. doi: $10.1177 / 0020715208093077$

Spring, J. H. (1976). The sorting machine: National educational policy since 1945: New York: McKay.

Støren, L. A., \& Arnesen, C. Å. (2003). Et kjønnsdelt utdanningssystem. In M. Raabe (Ed.), Utdanning 2003: Ressurser, rekruttering og resultater: Statistisk sentralbyrå.

Trappe, H. (2006). Berufliche segregation im Kontext. KZGS Kölner Zeitschrift für Soziologie und Sozialpsychologie, 58(1), 50-78.

van de Werfhorst, H. G. (2002). A detailed examination of the role of education in intergenerational social-class mobility. Social Science Information Sur Les Sciences Sociales, 41(3), 407-438.

Verdier, É. (2013). Lifelong Learning Regimes versus Vocational Education and Training Systems in Europe. The Growing Hybridisation of National Models. In A. Green, J. G. Janmaat \& P. Méhaut (Eds.), The Dynamics and Social Outcomes of Education Systems, Houndmills, Palgrave MacMillan (pp. 70-93). Houndmills: Palgrave Macmillan.

$\emptyset$ stbakken, K. M., Barth, E., \& Schøne , P. (2014). Hva betyr kjønnssegregering for lønn? In L. Reisel \& M. Teigen (Eds.), Kønnsdeling og etniske skiller på arbeidsmarkedet (pp. 205-220). Oslo: Gyldendal Akademisk. 